\title{
Realistic Mathematic Education pada Kemampuan Berpikir Kritis Siswa Sekolah Dasar
}

\author{
Ujiati Cahyaningsih, Dede Salim Nahdi
}

Universitas Majalengka

ujiati.cahyaningsih@gmail.com

\section{Article History}

accepted 24/09/2019

\begin{abstract}
he ability to think critically is needed to analyze a problem to the stage of finding a solution to solve the problem. Critical thinking means the process of reasoning a problem to the complex stages of "why" and "how" the process of solving it. The ability to think critically encourages students to come up with new ideas or thoughts about world problems. Students will be trained on how to select various opinions of people, so students can distinguish which opinions are true and not true. In addition, how to develop students' critical thinking skills by helping students make conclusions based on consideration of data and facts that occur in the field. RME is learning that emphasizes contextual and tangible matters relating to problems in daily life, so students can easily accept material and provide meaningful experiences to students. RME has special characteristics that are different from other approaches. The special feature is the context of realistic problems which are the starting point for learning mathematics, and the use of models to distinguish abstract mathematical worlds from the actual real world. Based on the understanding and characteristics of RME, then RME is a learning that can improve students' critical thinking skills.
\end{abstract}

Keyword: Realistic Mathematic Education, Mathematic Learning, Critical Thinking

\begin{abstract}
Abstrak
Kemampuan berpikir kritis memang diperlukan untuk menganalisis suatu masalah hingga pada tahap mencari solusi untuk menyelesaikan masalah tersebut. Berpikir kritis artinya proses melakukan penalaran terhadap suatu masalah sampai ke tahap kompleks tentang "mengapa" dan "bagaimana" proses pemecahannya. Kemampuan berpikir kritis mendorong siswa memunculkan suatu ide atau pemikiran yang baru mengenai permasalahan dunia. Siswa akan dilatih bagaimana menyeleksi berbagai pendapat orang, sehingga siswa dapat membedakan mana pendapat yang benar dan tidak benar. Selain itu, cara mengembangkan kemampuan berpikir kritis siswa dengan membantu siswa membuat kesimpulan berdasarkan pertimbangan data dan fakta yang terjadi di lapangan. RME adalah pembelajaran yang menekankan pada hal-hal yang kontekstual dan nyata yang berkaitan dengan masalah di kehidupan sehari-hari, sehingga siswa dapat dengan mudah menerima materi dan memberikan pengalaman yang bermakna pada siswa. RME memiliki karakteristik khusus yang berbeda dengan pendekatan lain. Ciri khususnya adalah adanya konteks permasalahan realistik yang menjadi titik awal pembelajaran matematika, serta penggunaan model untuk membedakan dunia matematika yang abstrak menuju dunia nyata yang sebenarnya. Berdasarkan pengertian serta karakteristik RME, maka RME merupakan suatu pembelajaran yang mampu meningkatkan kemampuan berpikir kritis siswa.
\end{abstract}

Kata kunci: Realistic Mathematic Education, pembelajaran matematika, Berpikir Kritis

Social, Humanities, and Education Studies (SHEs): Conference Series https://jurnal.uns.ac.id/shes

p-ISSN 2620-9284 e-ISSN 2620-9292 


\section{PENDAHULUAN}

Pendidikan pada saat ini bukan hanya sekedar kegiatan mentransfer ilmu dari guru kepada siswa. Lebih dari itu pendidikan merupakan suatu kegiatan yang bertujuan untuk menumbuhkan cara berpikir siswa menjadi lebih kritis dan kreatif dengan menggunakan berbagai sumber yang tersedia untuk memecahkan suatu masalah.

Variabel-variabel yang sering dikaji dalam hubungannya dengan kemampuan memecahkan masalah adalah metode yang digunakan guru dalam proses pembelajaran di sekolah. Kemampuan memecahkan masalah dapat di tingkatkan dengan cara meningkatkan kemampuan berpikir kritis dari siswa. Kemampuan berpikir kritis yaitu sebuah kemampuan yang dimiliki setiap orang dalam menerima informasi yang di terima dengan cara menganilsa lebih mendalam segala bukti yang ada serta dapat menyimpulkan informasi tersebut secara lebih spesifik.

Kemajuan ilmu pengetahuan dipengaruhi oleh cara belajar yang efektif, sehingga perlu adanya cara berpikir secara terarah dan terencana. Dengan banyaknya permasalahan yang muncul, perlu adanya pembaharuan di lingkungan pendidikan yang mengarahkan pada siswa agar dapat selalu berpikir kritis. Banyak yang beranggapan bahwa berpikir kritis memerlukan suatu tingkat kecerdasan yang tinggi. Padahal berpikir kritis dapat dilatih pada semua siswa untuk dipelajari. Disinilah manfaat atau peranan pendidikan yaitu memberikan suatu konsep atau cara belajar yang efektif.

Dalam interaksi pendidikan siswa tidak harus diberi atau dilatih, tetapi mereka dapat mencari, menemukan, dan memecahkan masalah. Siswa dilatih berperan aktif dan bertanggung jawab terhadap proses dan hasil pembelajaran yang mereka dapat. Disinilah peranan cara berpikir kritis, dimana proses pembelajaran dapat terlaksana dan berjalan secara efektif.

Kegiatan pembelajaran matematika diharapkan siswa mampu dan terampil dalam menyelesaikan masalah yang dihadapinya, baik dalam bidang matematika maupun dalam bidang lain. Kegiatan pembelajaran matematika diharapkan mampu membuat siswa berkembang daya nalarnya sehingga mampu berpikir kritis, logis, sistematis, dan pada akhirnya siswa diharapkan mampu bersikap obyektif, jujur dan disiplin. Fakta yang terjadi adalah guru dianggap sebagai sumber belajar yang paling benar. Proses pembelajaran yang terjadi memposisikan siswa sebagai pendengar ceramah guru yang baik. Akibatnya proses pembelajaran menjadi cenderung membosankan dan menjadikan siswa malas belajar. Agar siswa lebih aktif dalam pembelajaran dapat menggunakan berbagai macam pendekatan salah satunya adalah pendekatan Realistic Mathematics Education (RME).

Pendekatan Realistic Mathematics Education (RME) dikembangkan oleh seorang ahli matematika Freudenthal (Ariyadi, 2012:20), yang menegaskan bahwa matematika merupakan aktivitas manusia (human activity), dalam pembelajarannya siswa bukan hanya penerima pasif tetapi siswa perlu di beri kesempatan untuk reinvent (menemukan) matematika di kehidupan sehari-hari kepengalamanbelajar sesuai dengan materi yang di sajikan. Freudenthal yang berbunyi "Mathematics is a human activity"

Berdasarkan penjelasan-penjelasan yang telah disajikan, penulis tertarik untuk mengkaji lebih dalam mengenai model Realistic Mathematic Education dalam perannya menningkatkan kemampuan berpikir kritis siswa. Kajian ini merupakan kajian konseptual menggunakan studi literatur yang bersumber dari jurnal-jurnal yang terkait dengan model pembelajaran RME dan juga kemampuan berpikir kritis. 


\section{PEMBAHASAN}

Salah satu mata pelajaran yang dapat digunakan untuk memperkuat penalaran siswa adalah mata pelajaran matematika. Dalam pembelajaran matematika pengembangan penalaran terjadi jika siswa diajak untuk berpikir atau membangun pemahaman konsep materi pelajaran yang sedang dipelajari. Salah satu peran matematika bagi kehidupan adalah sebagai cara untuk berpikir, maka dapat dikatakan kamampuan berpikir/bernalar merupakan salah satu potensi yang harus dimiliki oleh siswa. (Wijaya, 2012)

Dalam pembelajaran matematika kemampuan berpikir kritis dapat dikembangkan jika seorang siswa secara rutin dihadapkan pada suatu masalah, sehingga siswa tersebut terlatih untuk memecahkan masalah. Dengan demikian, kemampuan berpikir kritis perlu dilatihkan dan diterapkan dalam proses pembelajaran, karena melatih kemampuan bernalar siswa tersebut.

Pendekatan pembelajaran yang dapat diterapkan dalam kegiatan pembelajaran matematika adalah Realistic Mathematics Education (RME) atau dikenal di Indonesia dengan Pendidikan Matematika Realistik Indonesia (PMRI). RME/PMRI dimaksudkan untuk memulai pembelajaran matematika dengan cara mengaitkannya dengan situasi dunia nyata di sekitar siswa (Muhsetyo, 2011:1.16). Dengan harapan melalui pendekatan ini siswa tertarik terhadap materi pelajaran matematika, mereka mudah menguasai berbagai konsep dan materi pelajaran namun tidak cepat lupa dengan apa yang telah diperolehnya, dan meningkatkan kemampuan berpikir, sehingga dapat meningkatkan prestasi belajarnya seperti yang terpampang dalam jurnal penelitian pendidikan Soviawati (2011)

Menurut Basman (dalam Anggraini, 2012) bahwa berpikir kritis dapat membantu peserta didik dalam meningkatkan pemahaman materi yang dipelajari dengan mengevaluasi secara kritis argumen pada buku teks, teman diskusi, dan argumen pendidik dalam pembelajaran. Jadi, jika siswa memiliki kemampuan berpikir ktitis, maka prestasi belajarnya akan bagus, karena siswa tersebut memahami konsep materi yang diajarkan. Dalam penelitian Nurhayati (2013) pendekatan pendidikan matematika realistik mampu meningkatkan kemampuan berpikir ktitis matematis peserta didik SMP, maka akan berlaku sama untuk peserta didik SD.

Secara umum pendekatan RME akan mengkaji tentang materi apa yang akan diajarkan beserta rasionalnya kepada siswa, bagaimana siswa belajar matematika, bagaimana topik-topik matematika seharusnya diajarkan, serta bagaimana menilai kemajuan belajar siswa tersebut. Suryanto, dkk., (2010) menyebutkan tiga prinsip pendekatan RME Guided reinventation and progressive mathematizing yakni menekankan pada penemuan kembali secara terbimbing.

Berdasarkan prinsip reinvention, siswa diberi kesempatan untuk mengalami proses yang sama dengan proses saat matematika ditemukan. Untuk itu, maka perlu ditemukan masalah konstektual yang dapat menyediakan berbagai macam prosedur penyelesaian serta mengindikasikan jalannya pembelajaran yang berangkat dari tingkat belajar matematika secara nyata ke tingkat belajar matematika secara formal (progressive mathemazing). Didactical phenomenoologi, penyajian topik matematika dalam pembelajaran matematika realistik disajikan atas dua pertimbangan yaitu memunculkan ragam aplikasi yang harus diantisipasi pada proses pembelajaran, dan kesesuaiannya sebagai hal yang berpengaruh pada proses progressive mathemazing. Self developed models, saat memecahkan masalah konstektual siswa diberi kesempatan untuk mengembangkan model mereka sendiri yang berfungsi untuk mengantarkan siswa pada pengetahuan informal dan matematika formal. Pada tahap pertama siswa mengembangkan model yang mereka ketahui. Selanjutnya melalui generalisasi dan pemformalan akhirnya model tersebut menjadi sungguh-sungguh ada (entity) yang dimiliki siswa. 
Gravemeijer (Tarigan, 2006, hlm. 5), "Ada lima tahapan yang harus dilalui siswa, yaitu penyelesaian masalah, penalaran, komunikasi, kepercayaan diri, dan representasi". Pertama penyelesaian masalah, pada tahap ini siswa diberikan masalah dalam bentuk soal kemudian diselesaikan menggunakan caranya sendiri, sehingga siswa dapat menggunakan pikirannya untuk menemukan ide dalam menyelesaikan soal tersebut. Dimana guru memberikan soal yang mudah dipahami oleh siswa berdasarkan tujuan pembelajaran yang akan dicapai (terkait dengan kehidupan seharihari). Selain itu, guru juga harus memberikan sedikit penjelasan untuk mengarahkan siswa pada masalah yang akan diselesaikan apabila siswa mengalami kesulitan. Kedua, penalaran adalah hal sangat penting pada tahap ini yaitu dimana siswa mampu menggunakan cara yang telah ia peroleh untuk menyelesaikan soal lain yang serupa. Dengan kata lain, siswa harus mampu mempertanggungjawabkan penemuannya tersebut melalui penyelesaian soal yang lainnya. Ketiga, komunikasi dimana artinya memberitahukan hasil jawaban yang diperoleh kepada temantemannya untuk didiskusikan, kemudian dibandingkan dengan jawaban teman yang lainnya. Pada tahap ini, siswa diberikan kesempatan untuk saling berdiskusi dan bertukarpikiran mengenai hasil jawaban yang diperoleh. Siswa dapat menyanggah apabila jawaban temannya dirasa kurang tepat. Keempat, rasa percaya diri yaitu setelah mendapatkan hasil dengan caranya sendiri, diharapkan mampu memperlihatkan jawabannya kepada teman-teman di depan kelas. Dengan penuh keyakinan siswa diharapkan mampu memberikan penjelasan yang tepat, apabila ada yang bertanya mengenai ketidakjelasan jawabannya. Kelima, representasi yaitu siswa diberikan kebebasan oleh guru untuk menyajikan hasilnya, apakah akan menggunakan lambang matematika atau benda-benda konkret untuk memudahkannya.

\section{SIMPULAN}

Berpikir kritis berarti melakukan proses penalaran terhadap suatu masalah sampai pada tahap kompleks tentang "mengapa" dan "bagaimana" proses pemecahannya. Kemampuan berpikir kritis dapat mendorong siswa memunculkan berbagai macam ide atau pemikiran baru mengenai permasalahan tentang dunia nyata. Siswa akan dilatih bagaimana menyeleksi berbagai macam pendapat, sehingga dapat membedakan mana pendapat yang relevan dan tidak relevan, mana pendapat yang benar dan tidak benar. Selain itu, pengembangan kemampuan berpikir kritis siswa dapat membantu siswa membuat kesimpulan dengan mempertimbangkan data dan fakta yang terjadi di lapangan. RME merupakan suatu pembelajaran yang menekankan pada hal-hal yang kontekstual dan nyata yang berkaitan dengan masalah dalam kehidupan sehari-hari, sehingga siswa dapat dengan mudah menerima materi dan memberikan pengalaman yang bermakna bagi siswa secara langsung. RME memiliki karakteristik khusus yang dapat membedakan RME dengan pendekatan yang lain. Ciri khusus ini adalah adanya konteks permasalahan realistik yang menjadi titik awal pembelajaran matematika, serta penggunaan model untuk menjembatani dunia matematika yang abstrak menuju dunia nyata. Berdasarkan pengertian serta karakteristik RME, maka RME merupakan suatu pembelajaran yang mampu dan dapat meningkatkan kemampuan berpikir kritis siswa.

\section{DAFTAR PUSTAKA}

Nurhayati, Yetty. (2013). Meningkatkan Kemampuan Representasi dan Berpikir Kritis Matematis Siswa SMP melalui Pendekatan Pendidikan Matematika Realistik

Sembiring, R.K. (2010). Pendidikan Matematika Realistik Indonesia(PMRI):Perkembangan dan Tantangannya. IndoMS. J.M.E. I, (1), hlm. 11-16..

ulita. (2014). Mengembangkan kemampuan berpikir kritis matematik melalui pembelajaran pencapaian konsep. Prosiding Seminar Nasional Pendidikan 
Matematika Program Studi Pendidikan Matematika STKIP Siliwangi Bandung (hlm. 69).

Karim \& Normaya. (2015). Kemampuan berpikir kritis siswa dalam pembelajaran matematika dengan menggunakan model Jucama di sekolah menengah pertama. Jurnal: Pendidikan Matematika, 3 (1), hlm. 93.

Maknun, C.L. (2012). Menumbuhkan kemampuan berpikir kritis matematis siswa melalui strategi pembelajaran PDEODE (Predict-Discuss-Explain-ObserveDiscuss-Explaine). Prosiding Seminar Nasional Cakrawala Pembelajaran Berkualitas di Indonesia (hlm. 250-268). Jakarta: Direktorat Pendidikan dan Tenaga Kependidikan Direktorat Jenderal

Suryanto. dkk. (2010). Sejarah Pendidikan Matematika Realistik Indonesia (PMRI). Yogyakarta: Direktur Ketenagaan Ditjen Dikti.

Tarigan, D. (2006). Pembelajaran matematika realistik. Jakarta: Depdiknas. 